\title{
From Passive to Radical Revolution in Venezuela's Populist Project
}

by

Ryan Brading

In December 2001, Hugo Chávez and others changed Venezuela's Bolivarian revolutionary project, which consisted of replacing a corrupt and elitist constitution with a fair and popular one, into a radical one. In its early stages the project corresponded to what Gramsci called a "passive revolution." Attempts by opposition forces to crush the construction of a new populist hegemony (a coup in April 2002 and an indefinite strike in December 2002) were met with popular mobilization that reaffirmed Chávez's hegemonic project. The radical revolution consisted of social programs designed to alleviate the suffering of the poor and consolidated a new hegemonic structure among Venezuela's lower classes. The concept of "radical revolution" provides a theoretical alternative for assessing the extent to which a political project can be described as populist.

En diciembre de 2001, Hugo Chávez y otros cambiaron el proyecto revolucionario bolivariano de Venezuela, que consistía en reemplazar una constitución corrupta y elitista por una justa y popular, por uno radical. En sus primeras etapas, el proyecto correspondió a lo que Gramsci definiera como una "revolución pasiva." Intentos por fuerzas de la oposición para frenar la construcción de una nueva hegemonía populista (un golpe de estado en abril de 2002 y una huelga indefinida en diciembre de 2002) se encontraron con una movilización popular que reafirmó el proyecto hegemónico de Chávez. La revolución radical consistió en programas sociales concebidos para aliviar el sufrimiento de los pobres y consolidó una nueva estructura hegemónica entre las clases inferiores de Venezuela. El concepto de "revolución radical" proporciona una alternativa teórica para evaluar la medida en que un proyecto político puede ser descrito como populista.

Keywords: Passive revolution, Bolivarian Revolution, Populism, Hugo Chávez, Luis Miquilena

A blog post by Adam David Morton (2012) called "WHAT IS THIS THING CALLED PASSIVE REVOLUTION?" reflects renewed interest in Gramsci's concept of the "passive revolution" and its relevance to various countries in Latin America (e.g., Argentina [Munck, 2013], Brazil [Coutinho, 2013; Del Roio, 2012], Chile [Motta, 2008], Guatemala [Short, 2007\}, and Mexico [Hesketh, 2010; Morton, 2003; 2007; 2010a; 2011]). Some slightly earlier studies in Spanish (e.g., Kanoussi and Mena, 1985; Portantiero, 1983) highlighted the usefulness of this

Ryan Brading obtained his Ph.D. in the Department of Government of the University of Essex and is currently a research fellow in the Institute of Latin American Studies, School of Advanced Study, University of London. His latest book is Populism in Venezuela (2013). He thanks all the participants, especially Jeremy Coles, for their feedback and the two LAP reviewers for advice and suggestions. 
concept. This article complements these studies by applying the concept to Venezuela, and it does so in relation to another phenomenon that has reemerged in the past 15 years in Latin America, populism.

In a passive revolution, according to Gramsci (1971: 105), influential groups want "their interests to dominate, rather than their persons; in other words, they want a new force, independent of every compromise and condition, to become the arbiter of the Nation." When the power structure of the nation is shifting, local groups with status and influence in the institutional framework displaced by the revolution want to "'dominate' and not to 'lead" "this revolutionary mode (105-106). In a passive revolution, the

State replaces the local social groups in leading a struggle of renewal. It is one of the cases in which these groups have the function of "domination" without that of "leadership": dictatorship without hegemony. The hegemony will be exercised by a part of the social group over the entire group, and not by the latter over other forces in order to give power to the movement, radicalise it, etc.

The Bolivarian Revolution led by Hugo Chávez promised change for Venezuela's unprivileged groups, but the dominant groups managed to secure their interests and create a position of power ("arbiter of the Nation") in this apparently new state. This follows Gramsci's observation that "one may apply to the concept of passive revolution the interpretative criterion of molecular changes which in fact progressively modify the pre-existing composition of forces, and hence become the matrix of new changes" (109).

In this article I argue that during the initial stages of Venezuela's Bolivarian revolutionary project much depended on the social, political, and economic involvement of both subaltern and dominant groups. This well-crafted arrangement claimed to represent the call for change of millions of Venezuelans. In practice, however, it was nothing but a modification of the preexisting alignment of forces. The privileged found ways of reinstating their interests and dominating the development of a passive revolution. This arrangement crumbled when Chávez challenged the moderate and dominant groups that had participated and invested in the revolution with radical policies that threatened their capital and their political interests. I maintain that, when a populist movement is determined to displace old hegemonic practices with a new hegemonic project for the underprivileged, the appropriate theoretical term for it is "radical revolution."

Regarding Morton's contribution to the revival of Gramsci's concept of the passive revolution, Ronaldo Munck (2011) notes that Morton's (2007) book Unravelling Gramsci "focuses on Gramsci's theory of uneven development and, with its extensive Latin America material, should be seen as a contribution to this task." Morton treats the history of Mexico as a passive revolution, explaining how "neoliberal restructuring in the 1980s and the 1990s led to a worsening crisis of hegemony-reminiscent of Gramsci's theme of a ruling class that is still dominant but not 'leading' or hegemonic." Munck (2011: 91-92) stresses that "Morton is urging us not to 'apply' Gramsci but, rather, to internalize his method of thinking to help create alternative futures."

I wish to contribute to the understanding of Chavismo by linking Morton's work, which focuses on categorizing and decoding the institutional grounding of modern states, with Ernesto Laclau's categories of the formation of 
hegemony in populism, which constructs an "us-them" axis to identify and challenge those opposing the decision to radicalize the revolution. This twist sheds light on the discursive implications of the Bolivarian revolutionary project in its early stages, using discourse-theoretical approaches to reread the relevance of passive revolution and suggesting how this concept applies to Chávez's dichotomous populist political agenda. This article provides a refinement of Gramsci's passive revolution, arguing that "passive" should be replaced with "radical" when populist forces radicalize a political project in order to construct and crystallize a new hegemonic institutional order.

Morton's terms are useful because they provide a set of tools for explaining how Venezuela's populist Bolivarian Revolution managed to expand and become consolidated when opposition sectors tried to block the radical changes that Chávez announced in the 49 enabling laws, attempted to oust him from the presidency in April 2002, and called an indefinite national strike in DecemberJanuary 2003. This analysis reveals that allies in Chávez's political project sought a passive revolution but their inability to dictate revolutionary processes after December 2001 led to a radical one-the crystallization of Chávez's us-them populist discourse. Empirically addressing how this revolution managed to produce a hegemonic platform and then to expand and become consolidated after a set of turbulent events results in a theoretical refinement of Gramsci's passive revolution.

To explain the nature, sociopolitical objectives, and impact of the Bolivarian Revolution, four questions need to be addressed. First, what social, political, and economic sectors supported and invested in the discourse of revolutionary change that Chávez advocated during his campaign for the presidency in December 1998? How did this promised revolution, after receiving the support of the majority of the electorate, begin to take shape, and what sectors of this dichotomized society decided to contest its continued development? Finally, how did a passive revolution become a radical revolution in the Venezuelan case?

The first section provides an overview of Morton's key terms, seeking to unfold the meaning of the analytical viewpoints he develops. The second section presents the empirical material and provides the analytical basis for the following discussion. Then, with the theoretical and empirical material in place and making use of Laclau's categories of populism, the final section demonstrates why it is appropriate to call the Venezuelan revolution a radical revolution.

\section{THE PASSIVE REVOLUTION}

Applying Gramsci's concept of "passive revolution" to the revolutionary changes Venezuela has seen in the past 15 years sheds new light on the efforts of influential sectors in this society to resolve their differences over the constitutional laws that Chávez implemented in December 2001. Morton (2012; see also 2007) suggests that the reading of Gramsci is a self-reflexive exercise that is based on the "purpose or form of engagement" — which means that "a 'true' or 'real' Gramsci cannot exist." He maintains that "there is no 'correct' reading of Gramsci that can be produced given that any understanding of his writings 
is circumscribed by specific interests and purposes." An interesting point here, because it resonates with the position of moderate Chavistas and dominant groups in Venezuela, is the meaning of the term "capitalist development": "[My] reading of passive revolution is that the condition and concept captures various concrete historical instances in which aspects of the social relations of capitalist development are either instituted and/or expanded, resulting in both 'revolutionary' rupture and a 'restoration' of social relations." In this context, "development" is a new way of presenting neoliberal measures for the apparent economic (capitalist) advancement of a wide range of social sectors in a society in which subjects support the discourse of "revolution" as a signifier of change (i.e., a better future). Regardless of class, race, economic, and ideological differences, the success of a political project that claims to hold high a revolutionary banner depends on the understanding and objectives that all its participants share. In Laclau's (2005a: 88-89, 95-96) theory of populism, this is the "equivalential chain." Morton (2012) suggests that "one way of regarding the condition and concept of passive revolution is to reflect on how elements of an insurrectionary force therefore become domesticated, which may involve a dialectical relation between processes of revolution from above and processes of revolution from below."

Here Morton introduces other interesting terms, one of which is "domesticated." The domestication of insurrectionary forces requires a social and political mechanism that deflates and subordinates the sectors that are most prone to rebel and to reject the meaning of "revolution" that other sectors articulate. If this domestication mechanism (from a poststructuralist perspective, the "nodal point" [Laclau and Mouffe, 1985: 112]) is overstretched, for example, by including more sectors that demand and expect the promised change, then this "revolution" will ultimately collapse. The real purpose of this revolution is to restore a framework in which opportunities for capitalist development are not restricted, making improvement of the lives of the less privileged sectors of the population a secondary objective.

Morton finds two processes linked to the passive revolution in Gramsci's Prison Notebooks. The first is "a revolution without mass participation, or a 'revolution from above,' involving elite-engineered social and political reform that draws on foreign capital and associated ideas while lacking a national-popular base." The second is the pressing of a revolutionary political transformation "into a conservative project of restoration . . . linked to insurrectionary mass mobilization from below." Morton continues by quoting Gramsci: The "fact that 'progress' occurs as the reaction of the dominant classes to the sporadic and incoherent rebelliousness of the popular masses-a reaction consisting of 'restorations' that agree to some part of the popular demands and are therefore 'progressive restorations, or 'revolutions-restorations,' or even 'passive revolutions' " (Gramsci, 2007: 252, Q8§25; see also Morton, 2010b: 318). Morton's interpretation of "revolution from above," with particular emphasis upon its being "elite-engineered," can help us understand the political apparatus that created the opportunity for Chávez to construct a convincing populist Bolivarian revolutionary discourse. This nontraditional, engineered political project helped Chávez to get elected in December 1998 and, through referendums, to cement the support of the people for a new and fair constitution (a key 
element of this passive revolution) promising to help poor Venezuelans who had few prospects.

Morton's term "elite-engineered" draws on Gramsci's analysis. The knowledgeable, better-educated elite know how to find the path to progress vis-à-vis the "sporadic incoherent rebelliousness of the popular masses," and this pact, uniting sectors of the elite with the popular masses, can work effectively in opposition. In government, however, social, political, and economic interests / strategies can change. If they do, then the differences among sectors are exposed and the equivalential chain achieved in opposition falls apart.

The popular universal demand for change/progress, which in effect subordinates but does not eliminate a range of different demands of the antagonistic sectors that support and invest in the equivalential chain, is what Laclau (2005b: 39) calls "hegemony." Further, with "equivalences, popular subjectivity, dichotomic construction of the social around an internal frontier, we have all the structural features to define populism" (38). Put another way, without a clear equivalential platform (constructed on an us-them axis ["dichotomic"] cementing its frontier with antagonistic sentiments-with offensive discourse, reviving dislocation between the marginalized and traumatized underdog and a repressive common enemy) that constructs a hegemonic framework for the excluded population, it will be impossible for populist politics to develop and institutionalize the promised state for the previously excluded population (see Brading, 2013: 43-88, 135-164, for a detailed analysis of the Venezuelan case).

As Morton (2010a: 8) points out, the Italian Resurgimiento has been understood as "a case of passive revolution and a mode of capitalist 'transition' in which hegemony is not achieved but the creation of a modern state becomes the requirement for social development." Since there is no hegemony in a passive revolution, it is inappropriate to call the political phenomenon "populist"; the use of political discourse that succeeds in mobilizing the masses is not sufficient. Thus, "'passive revolution' refers to processes of state formation that arise within an institutional framework consonant with capitalist social property relations. It involves the creation of a modern state as a precondition for the establishment of capitalism" (Gramsci, 1971: 106-107, quoted in Morton, 2010a: 8). Morton claims that the classic form of the passive revolution was the situation in which "the classes of the ancien régime managed to maintain a political role while new forms of power were developed to suit the expansion of capitalism under the tutelage of an emergent bourgeoisie" (21). Elsewhere (2007: 63) he argues that "the notion of passive revolution captures the subsequent attempt to establish the political rule of capital and the way in which processes of state formation are embedded in the circumstances of uneven and combined development."

Dylan Riley and Manali Desai (2007, cited by Morton, 2010a: 12), describe passive revolution as "a technique of statecraft that an emergent bourgeois class may deploy by drawing in subaltern social classes while establishing a new state on the basis of capitalism." In other words, passive revolution and capitalism go hand in hand. "The concept of passive revolution, it seems to me," said Gramsci (1996: 232, quoted in Morton, 2010a: 12)), "applies not only to Italy but also to those countries that modernize the state through a series of reforms" (Morton, 2010a: 12). In this context, "the notion of passive revolution, 
wedded to a critical consciousness, can be deployed with a 'spatial sense' that reveals . . . different insights about the uneven geography of state power" (Morton, 2010b: 331). Morton suggests that passive revolution as a "travelling theory"1 can help explain "the role played by "universal concepts with [specific] geographical seats' in approaching passive revolutions with different temporal and spatial characteristics within the historically specific conditions of capitalist production" (Gramsci, 1971: 117, Q10II§61, quoted by Morton, 2010b: 331).

The concept of passive revolution has been used to describe processes of development in Latin American countries. As Morton (2010a: 12, citing Löwy, 1981: 162-166, and Munck, 1979) observes, "Various passive revolutions (or 'semi-revolutions from above') have been recognized as drivers of the developmental catch-up process through planned action, the mobilization of the social base, and populist-style national development (e.g., in Mexico under Cárdenas [1934-1940], in Brazil under Getúlio Vargas [1937-1945], or in Argentina under Juan Perón [1944-1955])." In his Revolution and State in Modern Mexico (2011: 167) he says that democratization in Mexico is a perfect example of "passive revolution in which capitalism has been reorganized on a new institutional basis ensuring the survival of class power." What is interesting about this "passive revolution of democratic transition" in Mexico is that the influence of the United States as a capitalist figure is secondary. Rather, it is "a consequence of the internalization of the interests of capital that became integrated and contested across a scalar matrix combining local, state, and geopolitical levels." It "has to be situated within the internalization of specific moral and cultural values, codes of conduct, and ideological transformations in Mexico linked to the coexistent shift toward neoliberalism" (2011: 167-168). Nonetheless, one cannot help but wonder whether, had the popular and unconventional left-wing former governor of Mexico City, Andrés Manuel López Obrador (widely labeled a populist [see Grayson, 2007; Olmeda, 2008]), won the presidency in 2006, the path of Mexico's democratic system and capitalist development (safeguarded by the "elite-engineered" passive revolution institutional framework) would have been restored under pressure from the dominant classes or, alternatively, collapsed as it did in Venezuela.

\section{A PASSIVE REVOLUTION IN VENEZUELA'S POPULIST BOLIVARIAN REVOLUTIONARY PROJECT}

Chávez's victory in the December 1998 presidential elections would not have been possible without the support of social, political, and economic sectors that also wanted change in Venezuela's deeply fragmented society. After the failed military coup he had led on February 4, 1992, Chávez was imprisoned until March 1994. On his release with no restrictions on participating in political activities, he began to rebrand his clandestine Movimiento Bolivariano Revolucionario 200 (Revolutionary Bolivarian Movement 200-MBR 200) and welcomed other groups that were antagonistic toward the regime (López Maya, 2005: 167). In order to become an MBR 200 member, one had to undergo a ritual called the "Bolívarian promise," a promise to be honest, hardworking, 
humble, and supportive. "Bolivarian circles" were organized by town council coordinators in Caracas and regional coordinators in all the states of the country (López Maya, 2005: 170). According to Chávez, "social and political groups were indispensable, so we recognized the need to establish alliances. . . . We brought together several projects, which was the popular constitutional assembly; others included defending people's standards of living, defending national sovereignty ... called the 'organization of the popular movement'" (Harnecker, 2005: 42). The Bolívarian circles advocated the mobilization of the people to construct a new sociopolitical front demanding change.

The MBR 200's discourse stressed that "Venezuela's structural crisis requires radical solutions." Prior to the failed coup, the movement had had a clear political strategy: to overthrow the president, the National Assembly, the justices of the Supreme Court, and key members of the institutional structure and conduct a referendum to convoke a constitutional assembly (López Maya, 2005: 168). This political strategy did not change when the MBR 200 welcomed nonmilitary people into the movement; on the contrary, the movement strengthened its political position by incorporating other antagonistic social units. According to Chávez, this popular movement "began filling in the content of each project: each one needed a motor to drive forward"; at this stage, this "'civic-military MBR 200 movement' began to have formative experiences." It established Bolivarian committees in which members expressed their ideas / opinions for a constitutional assembly (Harnecker, 2005: 42-43). In addition to gathering national support and involvement through the Bolivarian circles, groups such as the Independientes para la Comunidad Nacional, Gente Emergente, Solidaridad Independiente, and the Asociación Agropecuaria also joined the Bolivarian project (López Maya, 2005: 221).

Chávez began to dress in a more casual Western fashion, but he made it clear that the military uniform was underneath and if necessary he would change and get ready for combat (Blanco, 1998: 512-513, cited by Marcano and Barrera Tyzka, 2006: 164-165). He repackaged his political stance with a more balanced discourse in order to expand his popularity and attract the middle class. On the political side of the movement, the MBR 200 (complying with the electoral rule against naming a political party after Bolívar) was changed to Movimiento V [Quinta] República (Fifth Republic Movement-MVR) ${ }^{2}$ in July 1997.

After Chávez's release from jail in 1994, Luis Miquilena ${ }^{3}$ became his political mentor. Chavez lived for a year in Miquilena's flat, where they discussed the problems Venezuela faced and how to improve the country peacefully and democratically. Miquilena was a "veteran practitioner with connections in the banking and insurance industries, some of whom helped finance Chávez's 1998 campaign" (Santodomingo, 2000, cited by Hellinger, 2003: 42). Business sectors, media groups, and influential people in Venezuela began to support Chávez's political project. Even a Venezuelan bank owned by a Spanish banking group donated US\$1.5 million for the campaign.

Chávez himself explained the importance of Miquilena in the construction of this revolutionary political project (Harnecker, 2005: 62) as follows:

We began to meet with groups and people, and that was when Luis Miquilena got involved because he is skilled politically. He organized the meetings with 
sectors of the left such as Causa R [a faction of this party later decided to form a new one called Patria Para Todos (Fatherland for All-PPT)], with sectors of the Movimiento al Socialismo [Movement for Socialism-MAS], ${ }^{4}$ and with other smaller parties like the Movimiento Electoral del Pueblo [People's Electoral Movement-MEP]).

From this political base, Chávez said, "we were able to form the Polo Patriótico, and Miquilena assumed a leadership role, showing great political skill. He earned a lot of respect among allies and potential allies alike."

The first political party to join the Polo Patriótico was PPT, and it was followed by the Partido Comunista de Venezuela (Communist Party of Venezuela-PCV), which announced: "'We support Comandante Chávez's candidacy"” (Harnecker, 2005: 62). PPT represented various trade unions and had a political presence in the shantytowns and in student organizations. All these political assets were vital for Chávez's victory (Medina, 2001: 110). In January 1998, the MAS's political committee was divided over the selection of potential presidential candidates to support. Chávez was only briefly mentioned, but in April he was included in the list because a key committee member (after a dialogue with him) had recognized the need to consider his political program. After receiving the results of a party grassroots survey, five and a half months prior to the election, the MAS (the third-largest political party) decided to join the Polo Patriótico. According to Felipe Mújica, the president of the MAS, "Even though many committee members strongly disagreed with MAS's involvement in the PP, it was recognized that ignoring nationwide social support at party regional branches would have been a serious political error" (see Brading, 2013: 57-58).

With the MAS in the Polo Patriótico, from June on Chávez's popularity kept increasing. The equivalential chain was expanding and strengthening its platform. Apart from a variety of political parties, a number of community assemblies (which played a key role in the construction of a radical political project) were campaigning for the election of a coup-plotter to the presidency. With a class-centered presidential campaign promising change for everyone and an end to corruption, Chávez was unbeatable. A large proportion of the middle-class and business sectors decided to support the change that he represented. Many capitalists also decided to jump on the bandwagon to safeguard their interests and, once Chávez was in government, to engineer the change from above that this Bolivarian Revolution promised. As a means to an end, they had to deal with Miquilena, the broker, and do business with a government in waiting.

The results of the December 6, 1998, presidential elections rubber-stamped the success of the Polo Patriótico equivalential chain when Chávez won with 56.20 percent of the vote..$^{5}$ The support of the MAS's political machinery was vital to his victory; more than half a million voters ( 9 percent of the total) chose the MAS. Chávez's nearest rival got 39.97 percent of the vote (see Brading, 2013: 58-59). The new political project promised change by replacing a corrupt and elitist constitution with a fair and popular one and by putting an end to corrupt practices and unscrupulous politicians who worked only for their own interests and those of their business cronies. This Bolivarian Revolution was presented to the people with a discourse that promised a drastic change in the 
institutional framework of the Venezuelan state. The development of the Bolivarian political project and the way it managed to pull together a wide selection of different sectors to support and invest in it bears a noticeable resemblance to Gramsci's passive revolution as Morton presents it.

From April 1999 until July 2000 there was a further expansion of this call for revolution. On April 25, 1999, a referendum on constitutional change was approved by more than 80 percent of the voters. On December 15, 1999, there was a referendum on the new constitution drawn up by the constitutional assembly elected earlier in the year, and more than 70 percent of the voters approved it. Gubernatorial, legislative, and presidential elections took place on July 30, 2000. In the elections for governors in 23 states, 17 Polo Patriótico candidates were elected; of the 165 legislative seats, 99 went to Polo Patriótico candidates. Chávez won comfortably with 59.76 percent.

For the new institutional structure to advance, Chávez was permitted to rule for a year by decree in six areas: the economy, transport and service infrastructure, science and technology, reorganization of government ministries, and crime. Mújica (interview, Caracas, March 16, 2009) recalls that

many influential media and economic sectors fully supported and invested in Chávez. However, when this new enabling-laws phase appeared and their substance was unknown, for the first time it created a sense of confrontation/ conflict with sectors from above and institutional divisions. To the political party MAS, Chávez was ignoring basic democratic principles; he didn't want to have any kind of dialogue with anyone.

Miquilena noted that "when the laws were presented (a total of 49 laws), there was no dialogue or debate whatsoever in the National Assembly (even among members of the Chavista camp) about substantive laws related to land reform, fishing rights, and hydrocarbons (oil)" (interview, Caracas, March 14, 2009). Miquilena, who was interior minister at that point, strongly disapproved of Chávez's land reform (which expropriated private land without negotiating with the landowner):

As the interior minister I had to deal with the business sector strike organized by the Federación de Cámaras y Asociaciones de Comercio y Producción de Venezuela [Venezuelan Federation of Chambers of Commerce-Fedecámaras] ${ }^{6}$ in December 2001. The strike ended after meetings I had with members of Fedecámaras, bankers, business groups, etc., acknowledging that the government ... would take a reasonable position with the business sectors.

However, early in the morning Chávez called saying that he would not sign any such agreement. The agreement was intended to initiate a dialogue, concessions, and agreements with the business community on the land reform, among other things. "This was my biggest clash with Chávez," Miquilena said. This was the moment when moderates and radical Chavistas split in the cabinet and the National Assembly (interview, Caracas, March 14, 2009).

Miquilena rejected the way radical changes were contaminating the structure of the National Assembly. He stressed that the radicals of the Chavista faction had abandoned the principle of political dialogue with the opposition. 
On January 8, 2002, he "demanded that the president reconsider his position and understand that a pact, a process of dialogue with other political members, was vital for the government." Days later he resigned. Chávez responded: "I'll never say goodbye to Miquilena, I'll always have him in my heart . . . the manager, strategist, his goodwill" (Hernández, 2002) Still, he went ahead with the radical changes. At this point the MAS also joined the opposition, and seven MAS legislators who opted to continue supporting Chávez in the National Assembly were expelled from the party.

Miquilena had mentored Chávez and played an important role in constructing the revolutionary political platform that helped him become president. However, in return he had expected to influence Chávez in the presidency. His decision to quit his post and break with Chávez alarmed many influential political organizations, capitalists, trade unions, and media outlets that had dealt with him. Internal fallout and the inability to restore equilibrium and make a pact with Chávez forced the opposition to think of ways to recover its position of dominance and stop the radical measures that Chávez and his supporters were implementing in the development of this new state.

Another influential sector that opposed Chávez's plan to radicalize the revolution was the oil industry. By February 2002, as the managers of the substantially autonomous state company Petróleos de Venezuela (PDVSA) were resisting the reforms he wanted in the industry, Chávez reacted by imposing a new board of directors largely made up of political loyalists rather than industry technocrats. A group of PDVSA managers "publicly denounced the "politicization' of the industry," and Venezuelan business interests, who were then moving into open conflict with the government, supported their condemnation. "Chávez responded in a high-handed manner when he sacked seven named PDVSA officials on television, during his 'Alo Presidente' program on April 7. This triggered a strike involving PDVSA and a series of other events that led to the failed coup attempt on April 11" (Philip and Panizza, 2011: 131). On April 9 PDVSA workers went out on strike, and they were joined by the Confederación de Trabajadores de Venezuela (Confederation of Workers of Venezuela-CTV) and Fedecámaras. Workers in the oil and aluminum industries sought to prolong the strike (Mendez, 2002). On April 11 anti-Chavistas gathered outside the PDVSA Chuao building in Caracas, and there it was "spontaneously" decided to march about 11 miles to the Presidential Palace, Miraflores. According to the opposition, Chávez ordered the police and the military to open fire on the protesters and high-ranking officials demanded his resignation. The next day the media announced that he had resigned, and the defense minister addressed the nation about the terms of the resignation. To fill the resulting "constitutional power vacuum," the military asked the president of Fedecámaras to assume the office of president. Soon after taking the post, Pedro Carmona Estanga abolished all constitutional powers and appointed a new government (see Brading, 2013: 71-72).

The degree of distress of the sectors that had expected to manage the revolution from above can be read from these events. The decision to abolish all constitutional powers was shocking, revealing a complete lack of respect for the decisions of the people in the elections that had taken place under Chávez's presidency. However, rumors that Chávez had not resigned quickly spread 
among the popular sectors: "This was a coup d'état." On April 13 people from the slums came down the hills and gathered outside Miraflores chanting "The people are with Chavez," "We want Chávez," "We want Chávez NOW," "We don't want a dictatorship ... yesterday they betrayed Venezuela-they violated our Constitution. "' Carmona's newly installed government panicked and left the Presidential Palace, and the very next day Chávez returned to office.

The next attempt to overthrow Chávez started on December 2, 2002. The business sectors and part of the oil industry joined the attempt along with a significant part of the leadership of PDVSA's merchant navy. The strike soon became "indefinite" — "until Chávez falls." The supply of gasoline dropped substantially, and the opposition used this to press the government to accept its demands. On January 23, 2003, the government organized its march. By this time the strike had run out of steam. By mid-February the government had secured full operational, managerial, and financial control of the oil industry. Toward the end of March, more than 18,000 managers and workers of PDVSA were fired for their involvement in the strike. Key sectors that opposed Chávez's interpretation of development in Venezuela had lost much of their credibility in the April 2002 coup, and the strike gave the government a motive to fire the anti-Chavista PDVSA employees involved in it and take full control of this valuable division of the state.

\section{FROM PASSIVE REVOLUTION TO RADICAL REVOLUTION}

During the initial stages of Chávez's political project, the relationship between Miquilena and Chávez flourished because they both wanted to dismantle the elitist and corrupt Punto Fijo institutional framework and create a new state with a fair constitution that enshrined the rights of every Venezuelan living under atrocious conditions. Miquilena's political and business experience, coupled with his established networking platform in these key circles, allowed Chávez to initiate a political project after being freed from prison in March 1994. The strategy was to construct a sociopolitical base centered on Chávez as the candidate for president in 1998. Chávez's moderate populist discourse capitalized on the failures of previous administrations in dealing with the growing problem of poverty and the exclusion of Venezuela's poor from the mainstream activities of society. The attempted coup of February 1992 gave him the opportunity to represent Venezuelans from the slums who supported his decision to overthrow an elitist institutional structure that benefited only the few.

Although Chávez had the right attributes to mobilize the masses-background, skin color, the desire to change a corrupt state, and so on-these qualities needed to be politically articulated and presented to the country. His campaign for the presidency succeeded in describing this new project as a legitimate one that sought institutional change and a new state for the people. Miquilena engineered an alliance with key political and business sectors with the key objective of replacing a discredited political system that had ruled the country since 1958 and, with the support of Venezuela's less privileged population, creating (without constructing a divisive hegemony) a modern state for 
the development of the people. The main purpose was to use Chávez as an emblematic figure to represent Venezuela's unprivileged, poor, and middle classes. From above, Chávez was a political tool acting as the president of this apparent revolution. The well-engineered political contract that consisted of having a populist leader using a discourse of justice and a better future for Venezuela's lower and middle classes was a perfect façade for this apparent new state. However, in practice the old mechanics of capitalism would have been restored and expanded to manage its development.

In its initial stages, this democratic call for revolution worked because it welcomed the participation and involvement of all sectors, from below as well as from above. Nonetheless, for this revolutionary framework to be established as a mode of governance in this deeply split society, the "conservative project of restoration" had to be dominant. Because conflicts of interest with business sectors began to appear in December 2001, it would be inaccurate to call the Bolivarian Revolution a passive revolution. The efforts to stop Chávez's radical constitutional changes, which were, to a large extent, a direct threat to the capitalists' development strategy, helped Venezuela's revolution identify its internal frontier (finally unmasking which sectors supported and which rejected a "true" revolution), reengineer the revolution, expand its horizons, and cement a radical populist project with a fully exposed us-them axis. The right conditions finally materialized for Chavista radicals to construct the promised true hegemony for Venezuela's underprivileged population.

This is the terrain on which a radical revolution from below was formed and reached unprecedented heights by challenging and dismembering the sectors from above that were determined to frustrate the popular will. As the conflict between the two camps intensified, it provided Chávez's government the opportunity to crystallize a radical Bolivarian hegemonic project. The attempts to displace Chávez brought to the surface the class-based political and economic disparities that had long dichotomized Venezuelan society. Confrontation gave the incumbent ammunition for the cultivation of resentment of people from marginal areas ("us") of other Venezuelans ("them") who were enjoying a higher standard of living.

At this stage the Bolivarian hegemony began to materialize. With the dichotomic terrain fully unveiled, Chávez's populist project shifted from a discourse promising to end an institutional system that benefited only the minority and improve the lives of Venezuela's less privileged population to a radical, democratically elected underdog configuration against the elitists and repressive groups that were attempting to restore their neoliberal hegemonic apparatus. As Morton (2010a: 8) points out, "Resurgimiento has been understood as a case of passive revolution and a mode of capitalist 'transition' in which hegemony is not achieved but the creation of a modern state becomes the requirement for social development." The strategy from above was to restore neoliberal practices and guarantee that they would not be affected by new constitutional and institutional practices. In this context, this new Bolivarian state could have claimed to be a revolution as it tried to promote social development for Venezuela's lower classes, but it would still have served the interests of the dominant classes because they had astutely engineered its formation. Attempts to construct a popular hegemonic project would have been subverted, because 
the dominant forces (neoliberals claiming to be revolutionists) within the government and the business sectors that invested in the project would have kept the sectors that were trying to articulate a radical call for change separated from each other.

Without the construction of a new hegemony, a radical revolution cannot crystallize. Filtering and refining the equivalential chain-removing moderate Chavistas and sectors that felt threatened by the political and economic implications of the enabling laws-was vital for the advancement of the Bolivarian revolutionary project. The events following Miquilena's failure to persuade Chávez to reconsider his relations with business sectors such as Fedecámaras laid the foundation for the development and expansion of the Bolivarian hegemonic project. As Laclau (2005a: 71) notes, "hegemonic totalization requires a radical investment," and the "affective dimension plays a central role here." On April 13, 2002, the decision of people from the slums of Caracas to protest outside the Presidential Palace for the return of their president was a clear sign of affection for the revolution that Chávez advocated and a clear call for radical changes to improve the lives of Venezuelans who felt excluded from the mainstream of society.

Had Chávez accepted a pact with the capitalists, weakening his position because of internal and external pressures, this new state would have been another contemporary case study confirming the theoretical contribution Gramsci made with his concept of the passive revolution. Without the spontaneous backing of the incoherent, rebellious lower classes, the Fedecámaras president chosen by the military to act as the interim president after the coup would have dismantled Chávez's political machinery and reinstated the neoliberal hegemonic structure that had governed Venezuela prior to Chávez's victory in 1998. There would have been no need to adopt an elite-engineered strategy. Finally, had Chávez stumbled rather than keeping his diehard supporters and political forces in the trenches-strategically observing how their enemies tried to overthrow him during an indefinite strike that virtually paralyzed the oil industry in December-January 2003-this political project would have failed to fulfill its full radical potential.

The rebellious lower classes radically invested for the return of their president to the Presidential Palace. People voted for Chávez because they expected a radical change in the country, not another passive pact safeguarding the interests of the capitalists and the dominant classes. As Mújica pointed out, it was the enabling laws that created a sense of confrontation between sectors and institutional divisions. In other words, this was the moment when Chávez decided to exchange the passive political position that had helped him win the presidency for a radical one.

The shift to radicalism was crucial for advancing his populist rhetoric to the next phase-the establishment of a new hegemony. As Laclau (2005b: 38) writes, "equivalential popular discourses divide ... the social into two camps: power and the underdog." All the attempts to oust Chávez from the presidency finally demarcated which sectors were with and which against his equivalential chain. The Miquilenistas (moderate Chavistas) had engineered a passive revolution that in fact was nothing but a reconfigured/revised neoliberal strategy concealed in a populist discourse of change and progress. Although Chávez 
succeeded in establishing his authority in the presidency after these critical events, the advancement of his revolutionary radical project required constant confrontational discourse against those who had ignored Venezuela's previously excluded population. Apart from the continuation of dichotomous discourse against the bourgeoisie, the oligarchs, unpatriotic traitors, faithful believers in neoliberalism, and so on, the next stage of the revolution added to its enemies list a bigger and more powerful external force: U.S. hegemony. This us-them axis provided Chávez the terrain he needed to cultivate this populist Bolivarian hegemonic project at home and in other regions of Latin America.

\section{CONCLUSION}

For a number of years Venezuela was a model of democracy for other Latin American countries (Levine, 1985: 58). However, by the 1990s this once stable institutional system had crumbled. Unexpected protests from the popular masses inflicted serious damage on a discredited and corrupt system implementing neoliberal policies. Efforts to resuscitate it were simply cosmetic. The failure to revive and modernize this institutional structure opened up the possibility of an alternative to the weak bipartite political system that had governed Venezuela since 1958 and offer voters a fair, participative, and inclusive new state for Venezuela's underprivileged population. With the involvement of alienated popular groups and the backing of small and medium-sized political parties and influential business sectors, Chávez won the presidency in December 1998.

The development of the new state in its early stages resonates with the Gramscian passive revolution that Morton describes. Morton's use of terms such as "capitalist development," "domesticated," "revolution from above" and "elite-engineered" cast light on important aspects of the dynamics that were supposed to restore and dictate capitalist policies in Chávez's revolution. The empirical material presented here, coupled with interviews with influential Chavistas, demonstrates the differences between moderate or Miquilenista and radical Chavistas and the business sectors that had expected a much different outcome in relation to capitalist interests than Chávez's enabling revolutionary laws. Disagreements and Chávez's uncompromising position forced anti-Chavistas to organize a set of events that sought to overthrow Chávez and his radical political agenda.

Gramsci's approach spells out important aspects of the development of a new state in this oil-rich Latin American country. Had Chávez agreed to the pact with the business sectors that Miquilena proposed in December 2001, this supposed Bolivarian revolution would-on the surface at least-have evolved by arguing that progress was possible only with the participation of the dominant classes. This arrangement would have maintained an equilibrium in which the lower classes would have been held at bay with Chávez's "passive" populist rhetoric, respecting the elite-engineered pact. However, the old capitalist production system would have restored its neoliberal policies and consolidated its "revolution from above." In other words, Venezuela would have been another example of Gramsci's passive revolution. 
Further rupture and conflict in many social, economic, and political spheres crystallized the drive for radical change that this new hegemonic project envisaged. These conditions provided Chávez's equivalential chain the missing ingredients to construct a radical hegemonic framework and galvanize the radical revolution that many Chavistas conceived. Capitalist development strategies and elite-engineering initiatives were out of the picture after the formation and expansion of the Bolivarian hegemonic project. The incoherent rebelliousness of the popular masses demanding the return of Chávez on April 13,2002 , was a clear reminder to the dominant classes that the only way to regain power was by electorally defeating Chávez. Henceforth, with a demoralized opposition and full control of the oil industry and its revenues, Chávez began to expand and cement the Bolivarian hegemonic project. The radical revolution that emerged consisted of a variety of social programs in marginal and rural areas of Venezuela (see Brading, 2013: 77, 89-113) that were designed to alleviate the suffering of the more than two-thirds of Venezuelans living in appalling conditions with little hope of improving their lives. The politicization of the oil industry and access to abundant oil revenues from 2003 on helped Chávez's government fund these social programs and consolidate a new hegemonic structure in Venezuela's lower classes.

\section{NOTES}

1. As Gramsci (1971: 108-109) notes, "since similar situations almost always arise in every historical development, one should see if it's not possible to draw from this some general principles of political science and art. One may apply to the concept of passive revolution (documenting it from the Italian Risorgimento) the interpretative criterion of molecular changes, which in fact progressively modify the composition of forces, and hence become the matrix of new changes." Gramsci considered the principles that shaped a passive revolution during the Italian Risorgimento applicable to other socio-historical, geographical, and economic circumstances. The concept of the passive revolution is called a "travelling theory" because it is not limited to the narratives that shaped it.

2. The Third Republic was established in 1811, when Spanish control ended and Venezuela became a province of Gran Colombia. In 1830 José Antonio Páez, a key independence leader, disagreed with the notion of Venezuela as a province and founded the Fourth Republic. Chávez represented the Fifth.

3. An experienced politician born in 1919 in Coro, Venezuela. His political career was important primarily for his position as secretary general of a trade union representing bus drivers in the 1940s. He was involved in various stages of political struggle in Venezuela and imprisoned during the periods of dictatorial rule. He was also the righthand man of Jovito Villalba, the founder of the Unión Republicana Democrática (Democratic Republican Union-URD), one of the three political movements in the Punto Fijo pact of 1961 (the others being Acción Democrática [Democratic Action-AD] and the Comité de Organización Política Electoral Independiente [Independent Political Electoral Organization Committee-COPEI]).

4. In 1971 a faction of the Communist Party of Venezuela decided to form a party promoting principles of pluralism and social democracy. The MAS quickly became the third-largest political party in Venezuela. In 1993, when the bipartite (AD and COPEI) 1961 Punto Fijo democratic system was in tatters, the MAS lent its political weight to the Chiripero alliance formed by the independent Rafael Caldera (the founder of COPEI and president of Venezuela from 1969 to 1974, who insisted, in spite of COPEI's rejection, on running for president in 1993 and was expelled from the party). This alliance was similar to Chávez's Polo Patriótico.

5. Polo Patriótico, 56.20 percent (MVR, 40.17 percent; MAS, 9.00 percent; PPT, 2.19 percent; PCV, 1.29 percent). Consejo Nacional Electoral, December 6, 1998. http://www.cne.gov.ve/estadisticas / e98_01.pdf (accessed October 2008). 
6. Fedecámaras is composed of chambers of commerce in 12 basic trade groups: banking, agriculture, commerce, construction, energy, manufacturing, media, mining, ranching, insurance, transportation, and tourism. During the first administration of the center-right President R. Caldera (1969-1974), this federation assumed vital importance in the political system. The economic radicalization put forward in the Bolivarian Revolution agenda was strongly rejected because it undermined core business principles.

\section{REFERENCES}

Blanco Muñoz, A.

1998 Venezuela del 04F-92 al 06D-98: Habla el Comandante Hugo Chávez testimonios violentos. Caracas: Cátedra Pío Tamayo/CEHA/IIES/FACES/UCV.

Brading, Ryan 2013 Populism in Venezuela. New York: Routledge.

Coutinho, Carlos Nelson 2013 Gramsci's Political Thought. Chicago: Haymarket Books.

Del Roio, Marcos 2012 "Translating passive revolution in Brazil." Capital and Class 36: 215-234.

Gramsci, Antonio 1971 Selections from the Prison Notebooks. Edited and translated by Quintin Hoare and Geoffrey Nowell-Smith. London: Lawrence and Wishart.

1996 Prison Notebooks. Vol. 2. Edited and translated by Joseph A. Buttigieg. New York: Columbia University Press.

2007 Prison Notebooks. Vol. 3. Edited and translated by Joseph A. Buttigieg. New York: Columbia University Press.

Grayson, W. George 2007 Mexican Messiah: Andres Manuel López Obrador. University Park: Pennsylvania State University Press.

Harnecker, Marta 2005 Understanding the Venezuelan Revolution: Hugo Chávez talks to Marta Harnecker. New York: Monthly Review Press.

Hellinger, Daniel

2003 "Political overview: the breakdown of Puntofijismo and the rise of Chavismo," pp. 27-53 in Steve Ellner and Daniel Hellinger (eds.), Venezuelan Politics in the Chávez Era: Class, Polarization, and Conflict. Boulder: Lynne Rienner.

Hernández, Taymen

2002 "Miguel puso a su cargo a la orden-Rodríguez Chacin sustituye a Miquilena." El Universal, January 25, 2002. http://www.eluniversal.com/2002/01/25/pol_art_25106DDD. shtml (accessed August 2008).

Hesketh, Chris

2010 "From passive revolution to silent revolution: class forces and the production of state, space, and scale in modern Mexico." Capital and Class 34: 383-407.

Kanoussi, Dora and Javier Mena

1985 La revolución pasiva: Una lectura de los Cuadernos de la Cárcel. Puebla: Universidad Autónoma de Puebla, Colección Ciencia Política.

Laclau, Ernesto

2005a On Populist Reason. London: Verso.

2005b "Populism: what's in a name?," pp. 32-49 in Francisco Panizza (ed.), Populism and the Mirror of Democracy. London: Verso.

Laclau, Ernesto and Chantal Mouffe 1985 Hegemony and Socialist Strategy: Towards a Radical Democratic Politics. London: Verso.

Levine, Daniel 1985 “The transition to democracy: are there lessons from Venezuela?" Bulletin of Latin American Research 4 (2): 47-61. 
López Maya, Margarita

2005 Del Viernes Negro al referendo revocatorio. Caracas: Alfadil Ediciones.

Löwy, Michael

1981 The Politics of Combined and Uneven Development: The Theory of Permanent Revolution. London: Verso.

Marcano, Cristina and Alberto Barrera Tyzka

2006 Hugo Chávez sin uniforme: Una historia personal. Barcelona: Debate.

Medina, Medófilo

2001 El elegido Presidente Chávez: Un nuevo sistema político. Bogotá: Ediciones Aurora.

Mendez, Gustavo

2002 "Guerra de desgaste/Se asegura prestación de servicios básicos CTV acude a la huelga indefinida." El Universal, April 11. http://www.eluniversal.com/2002/04/11/pol_art _11110AA.shtml (accessed August 2008).

Morton, Adam David

2003 "Structural change and neoliberalism in Mexico: 'passive revolution' in the global political economy." Third World Quarterly 24: 631-653.

2007 Unraveling Gramsci: Hegemony and Passive Revolution in the Global Political Economy. London: Pluto Press.

2010a "Reflections on uneven development: Mexican Revolution, primitive accumulation, passive revolution." Latin American Perspectives 37 (1): 7-34.

2010b "The continuum of passive revolution." Capital and Class 34: 315-342.

2011 Revolution and State in Modern Mexico: The Political Economy of Uneven Development. Lanham, MD: Rowman and Littlefield.

2012 "WHAT IS THIS THING CALLED PASSIVE REVOLUTION." For the Desk Drawer-Adam David Morton, July 11. http:// adamdavidmorton.com/2012/07/what-is-this-thing-called-passive-revolution/\#more-771 (accessed August 7, 2012).

Motta, C. Sarah

2008 'The Chilean Socialist Party (PsCh): constructing consent and disarticulating dissent to neo-liberal hegemony in Chile." British Journal of Politics and International Relations 10: 303-327.

Munck, Ronaldo

1979 "State and capital in dependent social formations: the Brazilian case." Capital and Class 3 (2): $34-53$.

2011 "Gramsci and Latin America." Latin American Perspectives 38 (6): 91-92.

2013 Rethinking Latin America: Development, Hegemony, and Social Transformation. New York: Palgrave.

Olmeda, C. Juan

2008 "Populismo, construcción política e instituciones: algunas reflexiones en torno al fenómeno López Obrador," pp. 171-190 in Julio Aibar and Daniel Vazquez (eds.), Política y sociedad en México. Mexico City: Facultad Latinoamericana de Ciencias Sociales.

Philip, George and Francisco Panizza

2011 The Triumph of Politics: The Return of the Left in Venezuela, Bolivia, and Ecuador. Cambridge: Polity Press.

Portantiero, Juan Carlos 1983 Los usos de Gramsci. Buenos Aires: Folio Ediciones.

Riley, Dylan J. and Manali Desai

2007 "The passive revolutionary route to the modern world: Italy and India in comparative perspective." Comparative Studies in Society and History 49: 815-847.

Santodomingo, Roger

2000 La conspiración 98: Un pacto para llevar a Hugo Chávez al poder. Caracas: Alfadil Ediciones.

Short, Nicola

2007 The International Politics of Post-Conflict Reconstruction in Guatemala. London: Palgrave. 